\title{
Biochemical and haematological responses to thermal stress in Labeo rohita (Hamilton, 1822) fingerlings
}

\author{
PREM KUMAR ${ }^{1}$, ASIM K. PAL ${ }^{2}$, NAROTTAM P. SAHU ${ }^{3}$, L. CHRISTINA ${ }^{1}$ AND ASHISH KUMAR JHA ${ }^{3}$ \\ ${ }^{1}$ Kakdwip Research Centre of ICAR-Central Institute of Brackishwater Aquaculture, South 24 Parganas - 743347 \\ West Bengal, India \\ ${ }^{2}$ ICAR-Central Institute of Fisheries Education, Yari Road, Versova, Mumbai - 400 061, Maharashtra, India \\ ${ }^{3}$ APC Nutrients (A unit of APC Global), 507, Minerva House, S. D. Road, Secunderabad - 500 003, Telangana, India \\ e-mail:prem.cife@gmail.com
}

\begin{abstract}
An experiment was conducted to understand the effect of thermal shock on stress and recovery in Labeo rohita (Hamilton, 1822) fingerlings. L. rohita fingerlings were exposed to a temperature of $38^{\circ} \mathrm{C}$ for $2 \mathrm{~h}$ and permitted to recuperate afterwards for $48 \mathrm{~h}$. Primary and secondary stress parameters were analysed after 2, 4, 8, 12, 24 and $48 \mathrm{~h}$ of recovery. The activity of glucose-6-phosphate dehydrogenase and acetylcholine esterase reduced significantly $(p<0.05)$. Erythrocytes, haemoglobin, respiratory burst activity and lysozyme levels increased significantly $(p<0.05)$ by 7.31, 23.91, 109.09 and $70.13 \%$ after thermal shock, whereas leucocytes, serum protein, albumin and globulin showed a reverse trend. During recovery, biochemical parameters normalised in $48 \mathrm{~h}$. However, immunological variables such as serum total protein, albumin and globulin, and histopathological changes in gill and kidney tissues did not return to normal condition.
\end{abstract}

Kewwords: Enzymes, Haematology, Histopathology, Labeo rohita, Stress recovery, Thermal stress

\section{Introduction}

Rohu Labeo rohita (Hamilton, 1822) is an economically important aquaculture species in India. The water temperature in freshwater bodies in India goes up to $34-37^{\circ} \mathrm{C}$ during summer months, which is beyond the optimum temperature for growth of this species (Das et al., 2005). During farming, fish are often exposed to several kinds of stressors, among which temperature is a major one, owing to the poikilothermic nature of fish. Therefore, any change in water temperature directly affects physiology of the fish (Jonassen et al., 1999). Stress responses activate the neuro-endocrine system that alters the body metabolism (Chatterjee et al., 2006). Most commonly studied stress response in fish and other vertebrates are primary responses which are measured as the level of cortisol and catecholamine (Barton and Iwama, 1991). Commonly measured parameters for secondary stress responses are blood glucose and lactate levels (Chatterjee et al., 2006). There is ample literature available on thermal stress responses in fishes; however, there is very limited information on the time required for normalisation of the stress responses and on the histopathological changes due to thermal stress. Therefore, the present study was carried out to understand the level of stress responses against heat shock and duration for recouping to normal state in L. rohita.

\section{Materials and methods}

Experimental animal

Fingerlings L. rohita (mean weight of $6.5 \pm 0.05 \mathrm{~g}$ ) were transported from a private fish hatchery to the laboratory in an open container (500 1) under oxygenation. The stock was acclimatised to laboratory conditions for a month and fed with a commercial diet.

\section{Experimental setup}

Ideal water temperature for Indian major carps (Catla catla, L. rohita and Cirrhinus mrigiala) is $28^{\circ} \mathrm{C}$ (Akhtar et al., 2012). However, carps can grow well between the temperature range of 18.3 and $37.8^{\circ} \mathrm{C}$ (Jhingran, 1975). Therefore, in this study L. rohita fingerlings were given heat shock at $38^{\circ} \mathrm{C}$. Six fishes maintained at $28^{\circ} \mathrm{C}$ were used as control. Forty-two fishes were randomly selected and exposed to thermal shock at $38^{\circ} \mathrm{C}$ for $2 \mathrm{~h}$ in a 701 glass aquarium, using a digital water heater to bring the water temperature to the desired experimental temperature of $38^{\circ} \mathrm{C}$. Immediately after $2 \mathrm{~h}$ of thermal shock $(0 \mathrm{~h}$ of recovery), six fishes were sampled. The remaining fishes were transferred back to the acclimatisation tank $\left(28^{\circ} \mathrm{C}\right)$ and sampled $(n=6)$ at an interval of 2, 4, 8, 12, 24 and $48 \mathrm{~h}$, of recovery.

Six fish from each samplings were anesthetised with clove oil $\left(50 \mu \mathrm{ll}^{-1}\right)$ and blood was collected by 
caudal vein puncture and pooled. Thereafter fishes were decapitated. Tissue homogenates of liver, brain, gill and muscle were prepared separately in sucrose solution $(0.25 \mathrm{M})$ and centrifuged at $5000 \mathrm{~g}$ for $10 \mathrm{~min}$ at $4^{\circ} \mathrm{C}$. The supernatants were collected and stored at $-20^{\circ} \mathrm{C}$ for further assays. Blood samples were allowed to clot for $2 \mathrm{~h}$, centrifuged at $3000 \mathrm{~g}$ for $5 \mathrm{~min}$ at $4^{\circ} \mathrm{C}$ and then kept at $-80^{\circ} \mathrm{C}$ until use. Pooled blood sample before clotting, was used for blood glucose estimation.

Enzyme analyses

Fructose-1, 6-diphosphatase

(D-FDP-1Phosphohydrolase; E.C. 3.1.3.11; FDPase) was assayed according to Freeland and Harper (1959). Adenosine triphosphatase (adenosine triphosphate phosphohydrolase, E.C. 3.6.1.3; ATPase) activity was measured as described by Post and Sen (1967). Phosphate released was estimated at OD of $660 \mathrm{~nm}$ (Kaplan, 1953). Glucose-6phosphate dehydrogenase ( $\alpha$-D-glucose-6 phosphate: NADP oxidoreductase; E.C.1.1.1.49; G6PDH) activity was measured by the method of the DeMoss (1953). Alkaline phosphatase (Orthophosphoric monoester phosphohydrolase, E.C.3.1.3.1; ALP) activity was measured according to the procedure detailed by Garen (1960). Acetylcholine esterase (acetyl hydroxylase, E.C.3.1.1.7; AChE) was estimated by the method of Hestrin (1949). Total protein in the sample was determined as per Lowry et al. (1951) for calculating the activity of enzymes. The absorbance of all the samples was measured in a UV-ViS spectrophotometer (E-Merck, Germany).

\section{Glucose and cortisol}

Estimation of blood glucose was done as per Nelson-Somogii (1945). Cortisol in serum was assessed by radioimmunoassay (RIA) as per the methods of Winberg and Lepage (1998).

\section{Haemato-immunological parameters}

\section{Blood haemoglobin $(\mathrm{Hb})$}

Blood $\mathrm{Hb}$ level was estimated by cyanmethemoglobin method using Drabkins fluid (Qualigens Diagnostics, Division of Glaxo Smithkline Pharmaceutical Ltd., India). Readings were taken at $540 \mathrm{~nm}$ in a spectrophotometer and haemoglobin content in the blood was calculated as:

Haemoglobin $(\mathrm{g} \%)=[\mathrm{OD}(\mathrm{T}) / \mathrm{OD}(\mathrm{S})] \mathrm{X}[251 / 100]$ X60

where, $\mathrm{OD}(\mathrm{T})=$ Absorbance of test; OD $(\mathrm{S})=$ Absorbance of standard

\section{Red blood cells and white blood cell counts}

Total erythrocyte and leucocyte counts were made using leucocyte and erythrocyte diluting fluid (Qualigens,
India) in haemocytometer. Twenty microlitre blood was diluted with $3980 \mu \mathrm{l}$ of diluting fluid in a test tube and mixed well to suspend the cells uniformly. Erythrocytes and leucocyte counts per $\mathrm{ml}$ of the blood sample were calculated as:

Number of cells $\mathrm{ml}^{-1}=($ Number of cells counted $\mathrm{x}$ dilution $) /$ (Area counted/Depth of fluid)

Serum total protein, albumin (A), globulin $(G)$ and $A / G$ ratio

Total protein and albumin kit (Qualigens Diagnostics) was used to estimate plasma total protein and albumin following Biuret and bromocresol green (BCG) dye binding method (Reinhold, 1953; Doumas et al., 1971). The value of globulin was calculated by subtracting albumin values from total protein and $\mathrm{A} / \mathrm{G}$ ratio was calculated by dividing albumin values with globulin values.

\section{Respiratory burst activity and serum lysozyme activity}

The respiratory burst activity was measured following the method of Secombes (1990). Fifty microlitre each of the blood sample was added to the wells of a U-bottom microtiter plates and incubated at $37^{\circ} \mathrm{C}$ for $1 \mathrm{~h}$ and washed thrice with phosphate buffered saline (PBS). After washing, $50 \mu \mathrm{l}$ of $0.2 \%$ nitroblue tetrazolium (NBT) was added and incubated for $1 \mathrm{~h}$. Adhering cells were fixed with $100 \%$ methanol, plates were air dried, and $60 \mu \mathrm{l}$ of $2 \mathrm{~N} \mathrm{KOH}$ and $70 \mu \mathrm{l}$ dimethyl sulphoxide (DMSO) were added. Optical density was measured at $540 \mathrm{~nm}$ in an enzyme-linked immunosorbent assay (ELISA) reader.

For analysing serum lysozyme activity, serum sample was diluted with phosphate buffer $(\mathrm{pH}$ 7.4) to a final protein concentration of $0.33 \mathrm{mg} \mathrm{ml}^{-1}$. Three millilitre of Micrococcus luteus was taken in a cuvet, to which $50 \mu \mathrm{l}$ of diluted serum sample was added. Optical density was measured in a spectrophotometer at $450 \mathrm{~nm}$ exactly $60 \mathrm{~s}$ after addition of serum sample and the absorbance was compared with standard lysozyme of known activity.

\section{Histopathological studies}

Tissue samples were fixed in neutral buffered formalin (NBF), dehydrated in ascending grades of ethanol $(70-100 \%)$, cleared in xylene, embedded in paraffin wax, and sections of $5 \mu$ thickness were cut using a microtome. The sections were stained with haematoxylin and eosin (H\&E) (Roberts, 1989) and observed under light microscope.

\section{Statistical analysis}

Differences among treatments for different stress responses were tested by one-way ANOVA and comparison 
of mean values was done using Duncan's multiple range tests at $5 \%$ level of significance $(\mathrm{p}=0.05)$. All statistical analyses were performed with SPSS 17.0 for Windows.

\section{Results and discussion}

Data on biochemical parameters analysed are presented in Table 1. Cortisol and blood glucose are the indicators of primary and secondary stress responses respectively (Kumar et al., 2014). A significant surge $(\mathrm{p}<0.05)$ in glucose and cortisol by 631.81 and $610 \%$, respectively was noticed after heat shock (Kumar et al., 2014) (Fig. 1a,b). However, both the parameters returned to normal values after $48 \mathrm{~h}$. Significant increase $(\mathrm{p}<0.05)$ in the activity of FDPase, ATPase, and ALP and decrease in the activity of G6PDH and AChE were noticed immediately after thermal shock. The activity of FDPase, a gluconeogenic enzyme, increased by 1212.62 and $2048.52 \%$ in liver and gill tissues respectively, which would have activated the gluconeogenic pathway to deal with the high energy needed during thermal stress. Further substrate for gluconeogenesis would have been delivered by transaminase activity (Kumar et al., 2014). In the current study, increase in ALP activity by 375.32 and $221.19 \%$ in liver and muscle tissues respectively would have caused breakdown of high-energy phosphate bonds that tolerate stress. ATPase hydrolyses the adenosine triphosphate (ATP) to sustain ionic gradient through the plasma membrane (Das, 2002). In the present investigation,

Table 1. Glucose-6-Phosphate Dehydrogenase (G6PDH in liver and gill), fructose-1, 6-Diphosphatase (FDPase in liver and gill), alkaline phosphatase (ALP in liver and muscle), adenosine triphosphatase (ATPase in liver and gill) and acetylcholine esterase (AChE in brain) activity in L. rohita fingerlings exposed to thermal shock of $38^{\circ} \mathrm{C}$ for $2 \mathrm{~h}$

\begin{tabular}{|c|c|c|c|c|c|c|c|c|c|}
\hline \multirow{3}{*}{$\begin{array}{l}\text { Recovery } \\
\text { period (h) }\end{array}$} & \multicolumn{9}{|c|}{ Biochemical parameters } \\
\hline & \multicolumn{2}{|c|}{ G6PDH } & \multicolumn{2}{|c|}{ FDPase } & \multicolumn{2}{|c|}{ ALP } & \multicolumn{2}{|c|}{ ATPase } & \multirow{2}{*}{$\frac{\mathrm{AChE}}{\text { Brain }}$} \\
\hline & Liver & Gill & Liver & Gill & Liver & Muscle & Liver & Gill & \\
\hline Control & $0.39^{\mathrm{a}} \pm 0.02$ & $0.06^{\mathrm{a}} \pm 0.01$ & $6.74^{\mathrm{e}} \pm 0.74$ & $5.07^{\mathrm{d}} \pm 1.75$ & $10.78^{d} \pm 0.33$ & $4.67^{\mathrm{g}} \pm 0.11$ & $3.95^{\mathrm{d}} \pm 0.37$ & $8.85^{\mathrm{f}} \pm 0.65$ & $25.91^{\mathrm{a}} \pm 0.01$ \\
\hline 0 & $0.29^{d} \pm 0.04$ & $0.05^{c} \pm 0.01$ & $88.47^{\mathrm{a}} \pm 0.50$ & $108.93^{\mathrm{a}} \pm 5.65$ & $51.24^{\mathrm{a}} \pm 0.72$ & $15.00^{\mathrm{a}} \pm .07$ & $9.65^{\mathrm{a}} \pm 0.39$ & $48.84^{\mathrm{a}} \pm 3.74$ & $8.01^{g} \pm 0.01$ \\
\hline 2 & $0.27^{e} \pm 0.06$ & $0.04^{\mathrm{d}} \pm 0.01$ & $87.73^{a} \pm 0.26$ & $107.55^{\mathrm{a}} \pm 4.26$ & $48.32^{\mathrm{a}} \pm 0.17$ & $13.56^{\mathrm{b}} \pm .07$ & $9.54^{\mathrm{a}} \pm 1.68$ & $46.82^{a} \pm 9.78$ & $9.53^{\mathrm{f}} \pm 0.01$ \\
\hline 4 & $0.27^{\mathrm{e}} \pm 0.03$ & $0.02^{\mathrm{f}} \pm 0.01$ & $83.94^{a} \pm 0.52$ & $96.86^{\mathrm{ab}} \pm 8.15$ & $38.35^{b} \pm 0.12$ & $12.48^{\mathrm{c}} \pm 0.04$ & $7.68^{b} \pm 0.12$ & $36.76^{b} \pm 10.23$ & $10.83^{e} \pm 0.01$ \\
\hline 8 & $0.29^{c} \pm 0.01$ & $0.03^{\mathrm{e}} \pm 0.01$ & $65.93^{b} \pm 2.26$ & $55.42^{\mathrm{abc}} \pm 6.48$ & $37.64^{b} \pm 0.54$ & $12.11^{\mathrm{d}} \pm 0.01$ & $6.80^{c} \pm 0.75$ & $31.04^{c} \pm 1.99$ & $15.17^{\mathrm{d}} \pm 0.01$ \\
\hline 12 & $0.30^{\mathrm{d}} \pm 0.02$ & $0.05^{b} \pm 0.01$ & $44.30^{c} \pm 0.30$ & $40.94^{\mathrm{bc}} \pm 10.63$ & $34.72^{\mathrm{c}} \pm 0.22$ & $11.09^{\mathrm{e}} \pm 0.05$ & $4.44^{\mathrm{d}} \pm 0.54$ & $24.54^{\mathrm{d}} \pm 5.72$ & $15.40^{\mathrm{c}} \pm 0.01$ \\
\hline 24 & $0.34^{b} \pm 0.09$ & $0.05^{b} \pm 0.01$ & $35.20^{\mathrm{d}} \pm 1.37$ & $26.99^{\mathrm{bc}} \pm 9.95$ & $10.93^{\mathrm{d}} \pm 0.11$ & $9.33^{\mathrm{f}} \pm 0.22$ & $4.09^{d} \pm 1.26$ & $16.73^{\mathrm{e}} \pm 10.89$ & $16.20^{c} \pm 0.01$ \\
\hline 48 & $0.38^{\mathrm{a}} \pm 0.05$ & $0.06^{\mathrm{a}} \pm 0.01$ & $5.86^{\mathrm{e}} \pm 0.36$ & $8.09^{\mathrm{d}} \pm 3.00$ & $10.47^{\mathrm{d}} \pm 0.04$ & $4.18^{g} \pm 0.03$ & $3.94^{\mathrm{d}} \pm 0.42$ & $9.10^{\mathrm{f}} \pm 4.24$ & $18.23^{b} \pm 0.01$ \\
\hline
\end{tabular}

Different superscripts in the same column indicate significant difference $(\mathrm{p}<0.05)$ amongst different recovery periods (Duncan's multiple range test, $\alpha=0.05)$. Values are expressed as mean $\pm \mathrm{SE}(\mathrm{n}=6)$. Unit: $\Delta 0.01$ optical density $\mathrm{mg}$ protein ${ }^{-1} \mathrm{~min}^{-1}(\mathrm{G} 6 \mathrm{PDH}) ; \mu \mathrm{g}$ phosphorous released $\mathrm{mg}$ protein ${ }^{-1}$ $\mathrm{min}^{-1}$ at $37^{0} \mathrm{C}$ (FDPase); $\mu \mathrm{M}$ acetylcholine hydrolysed $\mathrm{mg}$ protein ${ }^{-1} \mathrm{~min}^{-1}$ at $37^{0} \mathrm{C}$ (AChE); Nanomoles P-nitrophenol released $\mathrm{mg}^{-1} \mathrm{protein}^{-1} \mathrm{~min}^{-1}$ at $37^{0} \mathrm{C}$ (ALP); $\mu$ g phosphorous released $\mathrm{mg}$ protein ${ }^{-1} \mathrm{~min}^{-1}$ at $37^{0} \mathrm{C}$ (ATPase)
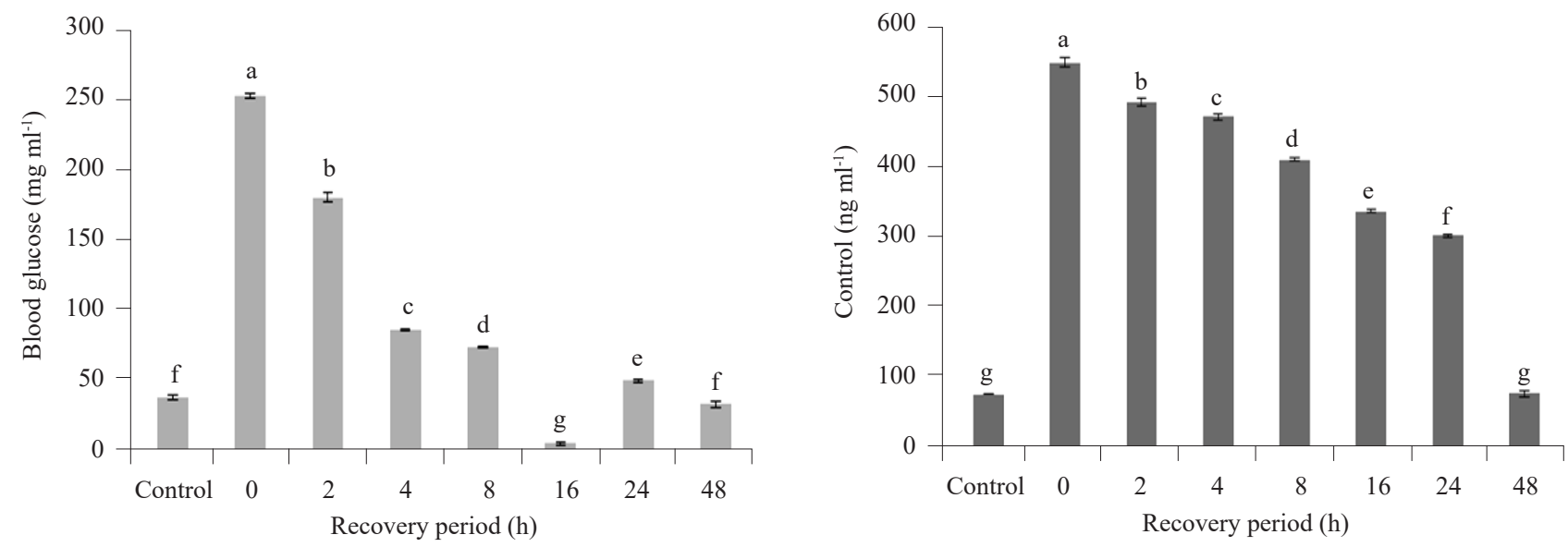

Fig. 1. (a) Blood glucose level and (b) Serum cortisol level of $L$. rohita fingerlings exposed to thermal shock of $38^{\circ} \mathrm{C}$ for $2 \mathrm{~h}$ and its recovery. Bars with different alphabets indicate significant difference during recovery period $(\mathrm{p}<0.05)$. Values are expressed as mean $\pm \mathrm{SE}(\mathrm{n}=6)$ 
ATPase activity increased by 144.30 and $451.86 \%$ in liver and gill tissues respectively, which signifies that there was no depletion of ATP after the thermal stress of $38^{\circ} \mathrm{C}$ for $2 \mathrm{~h}$. Similarly, increased activity of ATPase in response to stress to meet the energy requirement is reported in teleosts by Anderson (2016). G6PDH converts glucose6-phosphate to 6-phosphogluconolactone in pentose phosphate pathway using $\mathrm{NADP}^{+}$as a coenzyme and produces NADPH. This enzyme activity is expected to increase during high temperature (Verma et al., 2007). However, in the present study, G6PDH activity decreased by 25.64 and $16.66 \%$ in liver and gill tissues respectively after thermal stress, which might be due to the inhibitory action of cortisol on G6PDH (Tripathi and Verma, 2003). Reduction in the activity of AChE by $69.08 \%$ in brain tissue is similar to the observation made by Verma et al. (2007) in carp.

Data on total leucocyte count, erythrocyte count, haemoglobin, respiratory burst activity, plasma total protein, albumin, globulin and lysozyme activity are given in Table 2. Total erythrocyte count and haemoglobin level increased by 48.36 and $23.91 \%$ after thermal shock and returned to normal levels after $24 \mathrm{~h}$ of acclimation. The surge in erythrocyte and haemoglobin might be due to excess release of $\mathrm{RBC}$ from spleen into the general circulation to cope up with thermal stress by increasing the oxygen-carrying capacity. A similar observation was made by Randall and Perry (1992) due to acute stress in fishes. However, reduction in RBC and haemoglobin has been reported in L. rohita exposed to thermal stress for a longer duration (Akhtar et al., 2012). A significant drop in the leucocyte counts by $21.72 \%$ was noticed after thermal shock, which recouped to normal level in $48 \mathrm{~h}$. This is in agreement with the observations of
Verma et al. (2007) in Cyprinus carpio and Akhtar et al. (2012) in L. rohita. Reduction in leucocyte counts might be due to increased apoptosis, slow proliferation or redistribution of leucocytes from peripheral blood cells to lymphoid organs (Espelid et al., 1996). In the current study, NBT value increased by $109.09 \%$ after heat stress, which might be due to increased cortisol level, which induces lymphocytopenia and neutrophilia and further respiratory burst activity. This is similar to the observation made by Ruane et al. (2000). However, Akhtar et al. (2012) reported a reduction in respiratory burst activity due to thermal stress. There was a higher lysozyme activity (increase by $70.13 \%$ ) after thermal shock, which is comparable to the observation of Langston et al. (2002) in Atlantic halibut (Hippoglosus hippoglossus) caused by thermal stress. The total plasma protein, A, G and its ratio decreased significantly $(p<0.05)$ by $15.67,17.68,13.30$ and $5.08 \%$ respectively after thermal shock, which is in agreement with the observations of Akhtar et al. (2012) in L. rohita exposed to thermal and salinity stress. Such reductions might be due to the mobilisation of these compounds to fulfill energy requirement to cope with stress condition (Akhtar et al., 2012; Sarma et al., 2012).

Histopathological changes are widely used as biomarkers in the evaluation of the health status of fish (Camargo and Martinez, 2007). Histopathology of gills describes the general health condition of fish and quality of water (Peters et al., 1984). Thermal shock of $2 \mathrm{~h}$ did not affect liver tissue architecture in most of the fishes examined during the present study (Fig. 2), however in some fishes, the liver showed congested blood vessels (Fig. 3). After $48 \mathrm{~h}$, liver tissues appeared normal in architecture. Kidney tissue, after thermal shock showed congested blood vessels, vasodilatation and thickening of

Table 2. Levels of white blood cells (WBC), red blood cells (RBC), haemoglobin (HG), respiratory burst activity in NBT assay, total serum protein, albumin (A), globulin $(\mathrm{G}), \mathrm{A} / \mathrm{G}$ ratio and lysozyme activity of $L$. rohita fingerlings exposed to thermal shock of $38^{\circ} \mathrm{C}$ for $2 \mathrm{~h}$

\begin{tabular}{llllllllll}
\hline & \multicolumn{7}{c}{ Haematlogical parameters } \\
\cline { 2 - 10 } $\begin{array}{l}\text { Recovery } \\
\text { period (h) }\end{array}$ & WBC & RBC & HG & NBT & Total protein & Albumin (A) & Globulin (G) & A/G ratio & Lysozyme \\
\hline Control & $0.451^{\mathrm{a}} \pm 0.05$ & $1.22^{\mathrm{c}} \pm 0.01$ & $8.07^{\mathrm{c}} \pm 0.09$ & $0.11^{\mathrm{d}} \pm 0.00$ & $5.74^{\mathrm{a}} \pm 0.08$ & $3.11^{\mathrm{a}} \pm 0.01$ & $2.63^{\mathrm{a}} \pm 0.08$ & $1.18^{\mathrm{c}} \pm 0.01$ & $221.23^{\mathrm{a}} \pm 3.38$ \\
0 & $0.353^{\mathrm{c}} \pm 0.01$ & $1.81^{\mathrm{a}} \pm 0.03$ & $10.00^{\mathrm{a}} \pm 0.00$ & $0.23^{\mathrm{a}} \pm 0.01$ & $4.84^{\mathrm{b}} \pm 0.03$ & $2.56^{\mathrm{b}} \pm 0.06$ & $2.28^{\mathrm{b}} \pm 0.04$ & $1.12^{\mathrm{a}} \pm 0.04$ & $740.74^{\mathrm{a}} \pm 2.11$ \\
2 & $0.217^{\mathrm{d}} \pm 0.01$ & $1.66^{\mathrm{b}} \pm 0.01$ & $9.57^{\mathrm{b}} \pm 0.12$ & $0.22^{\mathrm{a}} \pm 0.00$ & $4.72^{\mathrm{b}} \pm 0.01$ & $2.36^{\mathrm{b}} \pm 0.02$ & $2.06^{\mathrm{c}} \pm 0.03$ & $1.15^{\mathrm{a}} \pm 0.03$ & $689.48^{\mathrm{b}} \pm 5.61$ \\
4 & $0.216^{\mathrm{d}} \pm 0.06$ & $1.56^{\mathrm{b}} \pm 0.01$ & $9.14^{\mathrm{b}} \pm 0.03$ & $0.19^{\mathrm{b}} \pm 0.00$ & $4.13^{\mathrm{c}} \pm 0.01$ & $2.21^{\mathrm{c}} \pm 0.01$ & $1.92^{\mathrm{d}} \pm 0.01$ & $1.15^{\mathrm{a}} \pm 0.01$ & $604.21^{\mathrm{c}} \pm 4.01$ \\
8 & $0.171^{\mathrm{a}} \pm 0.01$ & $1.52^{\mathrm{b}} \pm 0.00$ & $9.77^{\mathrm{b}} \pm 0.05$ & $0.18^{\mathrm{b}} \pm 0.00$ & $4.10^{\mathrm{c}} \pm 0.00$ & $2.17^{\mathrm{c}} \pm 0.00$ & $1.92^{\mathrm{d}} \pm 0.00$ & $1.13^{\mathrm{a}} \pm 0.01$ & $533.34^{\mathrm{d}} \pm 2.12$ \\
12 & $0.170^{\mathrm{e}} \pm 0.02$ & $1.44^{\mathrm{b}} \pm 0.01$ & $9.39^{\mathrm{b}} \pm 0.03$ & $0.13^{\mathrm{c}} \pm 0.01$ & $3.92^{\mathrm{d}} \pm 0.03$ & $2.09^{\mathrm{d}} \pm 0.01$ & $1.83^{\mathrm{d}} \pm 0.03$ & $1.14^{\mathrm{a}} \pm 0.02$ & $485.94^{\mathrm{e}} \pm 3.19$ \\
24 & $0.396^{\mathrm{b}} \pm 0.03$ & $1.28^{\mathrm{c}} \pm 0.01$ & $8.47^{\mathrm{c}} \pm 0.03$ & $0.12^{\mathrm{dc}} \pm 0.01$ & $3.69^{\mathrm{e}} \pm 0.02$ & $1.91^{\mathrm{e}} \pm 0.04$ & $1.56^{\mathrm{e}} \pm 0.05$ & $1.22^{\mathrm{a}} \pm 0.07$ & $264.79^{\mathrm{f}} \pm 8.90$ \\
48 & $0.449^{\mathrm{a}} \pm 0.03$ & $1.19^{\mathrm{c}} \pm 0.01$ & $8.49^{\mathrm{c}} \pm 0.03$ & $0.11^{\mathrm{d}} \pm 0.00$ & $3.47^{\mathrm{f}} \pm 0.02$ & $1.24^{\mathrm{f}} \pm 0.01$ & $2.41^{\mathrm{b}} \pm 0.03$ & $0.51^{\mathrm{b}} \pm 0.02$ & $224.39^{\mathrm{a}} \pm 6.41$ \\
\hline
\end{tabular}

Different superscripts in the same column indicate significant difference $(\mathrm{p}<0.05)$ among different recovery periods (Duncan's multiple range test, $\alpha=0.05)$. Values are expressed as mean $\pm \mathrm{SE}(\mathrm{n}=6)$. Unit: $\mathrm{RBC}\left(\mathrm{x} 10^{6}\right.$ cells $\left.\mathrm{mm}^{-3}\right)$, WBC $\left(\mathrm{x} 10^{5}\right.$ cells $\left.\mathrm{mm}^{-3}\right)$, haemoglobin content $\left(\mathrm{g} \mathrm{dl}{ }^{-1}\right)$, NBT (absorbance at $540 \mathrm{~nm}$ ), serum total protein $\left(\mathrm{g} \mathrm{dl}^{-1}\right)$, albumin $\left(\mathrm{g} \mathrm{dl}^{-1}\right)$, globulin $\left(\mathrm{g} \mathrm{dl}^{-1}\right)$, lysozyme activity (unit $\mathrm{min}^{-1} \mathrm{mg}$ serum protein $\left.{ }^{-1}\right)$ 


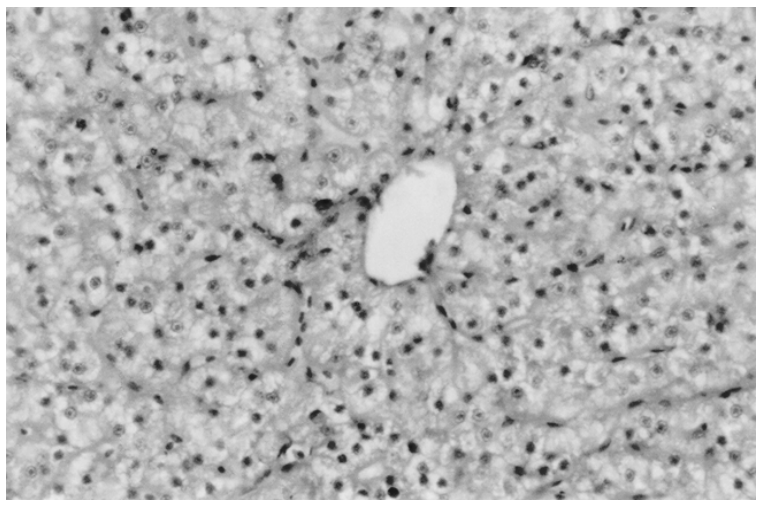

Fig. 2. Liver tissue section of L. rohita showing normal architecture and staining characteristics of the hepatocytes (H\&E; X160)

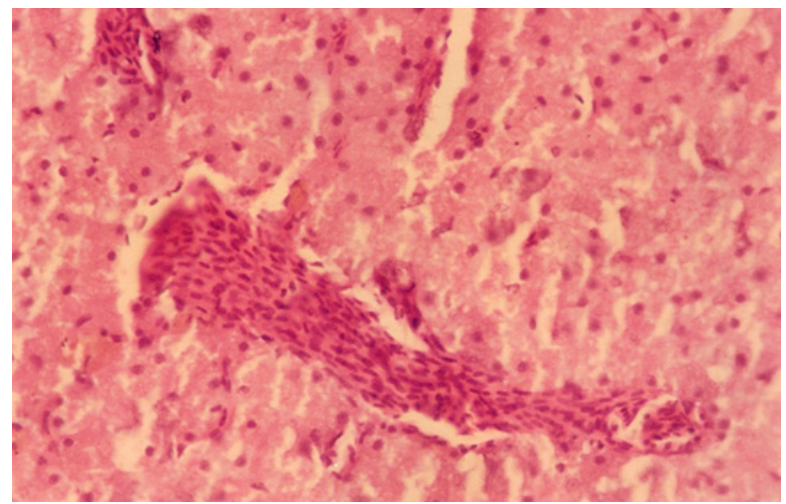

Fig. 3. Liver tissue section of L. rohita exposed to thermal shock of $38^{\circ} \mathrm{C}$ for $2 \mathrm{~h}$ showing congested blood vessels (arrow) (H\&E; X160)

arterial wall and sloughing of endothelial cells (Fig. 4). Gill tissue of fishes exposed to heat shock showed lamellar tissue destruction and mild hyperplasia at the base of gill lamellae (Fig. 5). Similar observation was made by Solid et al. (2005) in Carassius carassius. Degeneration of lamellar tissue could be attributed to direct heat shock, which is in par with the observation of Temmink et al. (1983) in rainbow trout.

In conclusion, acute thermal stress noticeably affects the physiology and stress responses of $L$. rohita fingerlings. During recovery, biochemical parameters recouped to normal levels in $48 \mathrm{~h}$ post-thermal shock. However, immunological variables such as serum total protein, albumin and globulin and histopathological changes in gill and kidney tissues did not return to normal conditions in $2 \mathrm{~h}$. These findings have ecological significance from the perspective of environmental changes and global warming.

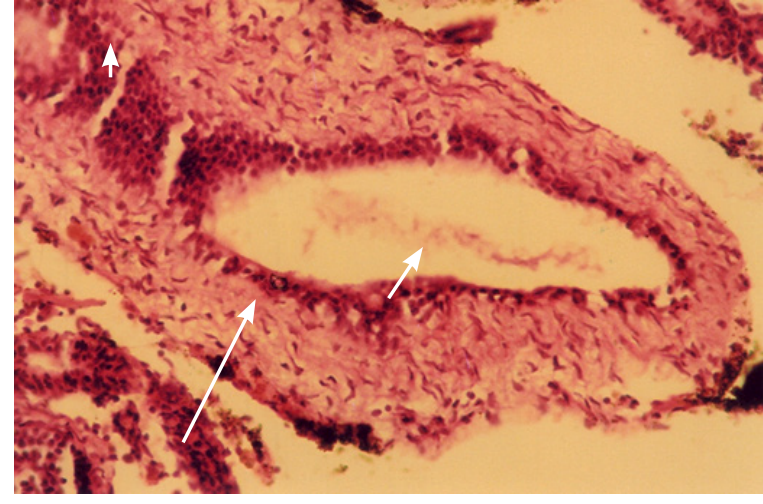

Fig. 4. Kidney tissue of L. rohita fingerlings exposed to thermal shock of $38^{\circ} \mathrm{C}$ for $\mathrm{h}$ showing thickening of arterial wall (large arrow), endothelial cells sloughing (arrow head) and vasodilatation (small arrow) (H\&E; X160)

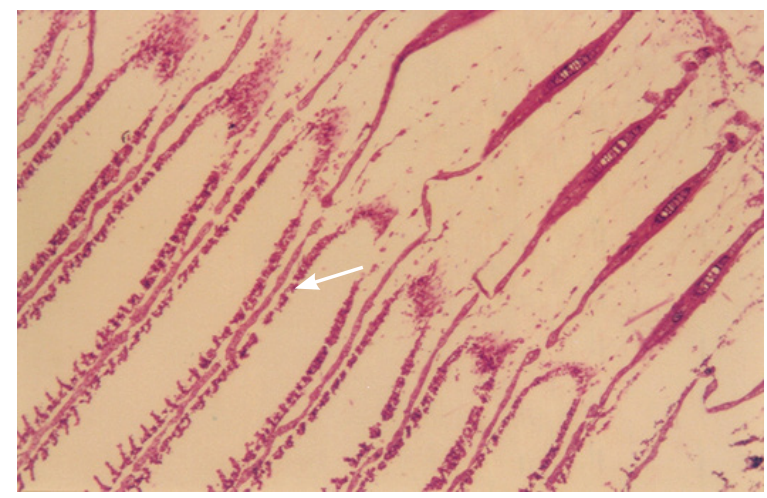

Fig. 5. Gill tissue of L. rohita fingerlings exposed to thermal shock of $38^{\circ} \mathrm{C}$ for $2 \mathrm{~h}$ showing lamellar tissue destruction (arrow) (H\&E; x40)

\section{Acknowledgements}

Authors sincerely thank the Director, ICAR-Central Institute of Fisheries Education, Mumbai, for the support extended for conducting this research work.

\section{References}

Anderson, A. M. 2016. Physiology of stress responses in teleost fish. Honors Theses, AY 15/16, University of Wyoming, USA, $85 \mathrm{pp}$.

Akhtar, M. S., Pal, A. K., Sahu, N. P. and Ciji, A. 2012. Hematoimmunological responses of Labeo rohita juveniles to temperature and salinity stress: Effect of dietary L-tryptophan. Isr. J. Aquac. Bamidgeh., 65.2013.892: 8 pp

Barton, B. A. and Iwama, G. K. 1991. Physiological changes in fish from stress in aquaculture with emphasis on the response and effect of corticosteroids. Annu. Rev. Fish Dis., 1: 3-26. 
Chatterjee, N., Pal, A. K., Das, T., Manush, S. M., Sarma, K., Venkateshwarlu, G. and Mukherjee, S. C. 2006. Secondary stress response in Indian major carps Labeo rohita (Ham), Catla catla (Ham) and Cirrhinus mrigala (Ham) fry to increasing packing densities. Aquac. Res., 37: 472-476.

Camargo, M. M. P. and Martinez, C. B. R. 2007. Histolopathology of gills, kidney and liver of a Neotropical fish caged in an urban stream. Neotrop. Icthyol., 5(3): 327-336.

Das, D. 2002. Metabolism of proteins. In: Das, D. (Eds.), Biochemistry. Academic Publishers, New York, p. 463-504.

Das, T., Pal, A. K., Chakraborty, S. K., Manush, S. M., Sahu, N. P. and Mukherjee, S. C. 2005. Thermal tolerance, growth and oxygen consumption rate of Labeo rohita fry (Hamilton, 1822) acclimated to four temperatures. J. Thermal Biol., 30: $378-383$.

DeMoss, R. D. 1953. Glucose-6-phosphate and 6-phospho gluconic dehydrogenase from Leuconostoc mesenteroids. In: Colowick, S. P. and Kaplan, N. O. (Eds.), Methods in enzymology, vol. I, Academic Press Inc., New York, p. 328-332.

Doumas, B. T., Watson, W. and Biggs, H. G. 1971. Albumin standards and measurement of serum albumin with bromocresol green. Clin. Chim. Acta, 31: 87-96.

Espelid, S., Lokken, G. B., Steiro, K. and Bogwald, J. 1996. Effects of cortisol and stress on the immune system in atlantic salmon (Salmo salar). Fish Shellfish Immunol., 6: 95-110.

Freeland, R. A. and Harper, A. L. 1959. The study of metabolic pathway by means of adaptation, J. Biol. Chem., 234: $1350-1354$

Garen, A. and Levinthal, C. A. 1960. Fine-structure genetic and chemical study of the enzyme Alkaline phosphatase of E. coli. I. Purification and characterization of Alkaline phosphatase. Biochem. Biophys. Acta, 38: 470.

Hestrin, L. 1949. The reaction of acetyl choline esters and other carboxylic acid derivatives with hydroxylamine and its analytical application. J. Biol. Chem., 180: 249-261.

Jhingran, V. G. 1975. Fish culture in freshwater ponds. In: Jhingran, V. G. (Ed), Fish and fisheries of India, 276 pp.

Jonassen, T. M., Imsland, A. K. and Stefansson, S. O. 1999. The interaction of temperature and fish size on growth of juvenile halibut. J. Fish. Biol., 54: 556-572.

Kaplan, N. O. 1953. Methods in enzymology, vol. I. Academic Press, New York, p. 328-332.

Langston, A. L., Hoare, R., Stefansson, M., Fitzgerald, R., Wergeland, H. and Mulcahy, M. 2002. The effect of temperature on non-specifc defence parameters of three strains of juvenile Atlantic halibut (Hippoglossus hippoglossus L.). Fish Shellfish Immunol., 12(1): 61-76.

Lowry, O. H., Ronebrough, N. J., Farr, A. L. and Randall, R. J. 1951. Protein measurement with Folin Phenol Reagent. J. Biol. Chem., 193: 265-276.
Nelson-Somogii 1945. Cited by Oser, B. L., 1965. In: Hawk's Physiological Chemistry, $14^{\text {th }}$ edn. McGraw Hill Publication, New York, 113 pp.

Peters, G., Hoffmann, R. and Klinger, H. 1984. Environmental induced gill disease of cultured rainbow trout (Salmo gairdneri). Aquaculture, 38: 105-126.

Post, R. and Sen, A. K. 1967. Methods in enzymology, vol, 10. Academic Press, New York, 762 pp.

Kumar, P., Asim, K. Pal., Narottam. P. Sahu., Ashish, K. Jha and Priyadarshani, Priya. 2014. Biochemical and physiological stress responses to heat shock and their recovery in Labeo rohita fingerlings. Proc. Natl. Acad. Sci. India, Sect. B Biol. Sci., 85(2): 485-490.

Randall, D. J. and Perry, S. F. 1992. Ctecholamines. In: Hoar, W. S. and Randall, D. J. (Eds.), Fish physiology, vol. 12. Academic Press, New York, p. 255-300.

Reinhold, J. G. 1953. Manual determination of serum total protein, albumin and globulin fractions by Biuret method. In: Reiner, M. (Ed.), Standard method of clinical chemistry. Academic Press, New York, 88 pp.

Roberts, R. J. 1989. Nutritional pathology of teleosts. In: Roberts, R. J (Ed.), Fish pathology, Bailliere Tindall, London, p. 337-362.

Ruane, N. M., Nolan, D. T., Rotlant, J., Costelloe, J. and Wendellar Bonga, S. E. 2000. Experimental exposure of rainbow trout Oncorhynchus mykiss (Walbaum) to the infective stages of the sea louse Lepeoptheirus salmonis (Kroyer), influences the physiological response to an acute stressor. Fish Shellfish Immunol., 10 : 451-463.

Sarma, K., Pal, A. K., Sahu, N. P., Dalvi, R. S., Nirupama Chatterjee., Mukherjee, S. C. and Kartik Baruah. 2012. Acute and chronic effects of endosulfan on the haematoimmunological and histopathological responses of a threatened freshwater fish, spotted murrel, Channa punctatus. Fish Physiol Biochem., 38: 499-509.

Secombes, C. J. 1990. Isolation of salmonid macrophage and analysis of their killing ability. In: Stolen, J. S., Fletcher, T. C., Anderson, D. P., Roberson, B.S., Van, W. B. and Winkel, M. (Eds.), Techniques in fish immunology, SOS Publication, New Jersey, USA, p. 137-152.

Solid, J., Weber, R. E. and Nilsson, G. E. 2005. Temperature alters the respiratory surface area of crucian carp Carassius carassius and gold fish carassius auratus. J. Exp. Biol., 208: 1109-1119.

Tripathi, G. and Verma, P. 2003. Pathway-specific response to cortisol in the metabolism of catfish. Comp. Biochem. Physiol., B., 136: 463-471.

Temmink, J., Bowmieister, P., Jong, P and Van der Berg, J. 1983. An ultrastructural study of chromate-induced hyperplasia in the gill of rainbow trout, Salmo gairdneri. Aquat. Toxicol., 4: 165-179. 
Verma, A. K., Pal, A. K., Manush. S. M., Das, T., Dalvi, R. S. and Chandrachoodan, P. P. 2007. Persistent sub-lethal chlorine exposure augments temperature induced immunosuppression in Cyprinus carpio advanced fingerlings. Fish Shellfish Immunol., 22: 547-555.
Winberg, S. and Lepage, O. 1998. Elevation of brain 5-HT activity, POMC expression and plasma cortisol in socially subordinate rainbow trout. Am. J. Phisiol., 43: $645-$ 654 .

Date of Receipt $\quad$ : 27.03.2018

Date of Acceptance : 17.05.2019 